Review

\title{
Crucial technologies supporting future development of petroleum refining industry
}

\author{
LI Dadong* \\ SINOPEC Research Institute of Petroleum Processing, Beijing 100083, China
}

\section{A R T I C L E I N F O}

\section{Article history:}

Received 20 November 2012

Accepted 30 December 2012

Published 20 January 2013

\section{Keywords:}

Residue

Asphaltenes

Gasoline

Diesel

Catalytic hydrogenation

Fluid catalytic cracking

Propylene

\begin{abstract}
A B S T R A C T
The primary tasks of refineries in the future are to improve the yield of light oil and to produce clean fuels and high-quality chemical raw materials. The efficient conversion of heavy oil is necessary to improve the yield of light oil. This conversion requires some crucial technologies, including: (1) residue hydrotreating technology, (2) the research institute of petroleum processing's (RIPP's) integrated combination process for residue hydroprocessing, (3) the integration of selective hydrogenation of fluid catalytic cracking gas oil with selective catalytic cracking process, and (4) the combination of superficial solvent deasphalting, hydrotreatment of deasphalted oil, and fluid catalytic cracking technology. The most important technologies for producing clean fuels such as qualified gasoline and diesel include the RIPP's selective hydrodesulfurization technology, the RIPP's hydrogenation technology for producing ultra-low-sulfur diesel fuel, and catalysts for producing RS-1000 and RS-2000 (grades of ultra-low-sulfur diesel). To produce high quality chemical raw materials, the Sinopec hydroprocessing for maximum propylene of fluid catalytic cracking process is of vital importance. The characteristics and effects of these technologies are summarized in this article.
\end{abstract}

(C) 2013, Dalian Institute of Chemical Physics, Chinese Academy of Sciences. Published by Elsevier B.V. All rights reserved.

\section{Introduction}

An increasing proportion of heavy and sour (high-sulfur) crude oil is being processed globally, resulting in deteriorating crude oil quality. In 1996, sour and high-sulfur crudes represented $57 \%$ and heavy crudes represented $11.1 \%$ of total global oil production, whereas in 2010 these proportions grew to $75.0 \%$ for sour and high-sulfur crudes and $15.6 \%$ for heavy crudes. Based on an analysis of available crude resources, refineries of all countries, including China, will continue processing a growing amount of inferior crude oil in the future.

Increasingly stringent environmental regulations are accelerating improvements in petroleum product quality in China. Beginning March 1, 2008, the Beijing metropolitan area began enforcing the national IV emission standard, which was equivalent to the Euro IV standard and specified a $50 \mu \mathrm{g} / \mathrm{g}$ limit for the sulfur content in gasoline. At the same time, other regions of China continued enforcing a less stringent requirement that was equivalent to the Euro II emission standard. Starting in 2010, Shanghai and Guangzhou began enforcing an emission standard equivalent to the Euro IV standard, with the remainder of China enforcing the Euro III emission standard. Since May 2012, Beijing has been enforcing the national V standard, requiring less than $10 \mu \mathrm{g} / \mathrm{g}$ of sulfur content in automotive gasoline or diesel fuel. The result of these environmental regulations is that future automotive fuels will tend to have ultra-low sulfur contents, for example, less than $10 \mu \mathrm{g} / \mathrm{g}$ sulfur, as needed to comply with the Euro $\mathrm{V}$ emission standard that requires nearly sulfur-free fuel. Those fuel grades that cannot meet this stringent emission standard would not have access to the market.

As China's crude oil quality continues to deteriorate, Chi- 
nese refineries are facing severe challenges to increase their light distillate yield while also complying with increasingly stringent environmental regulations. China's refineries are actively engaged in developing technical innovations and technologies to address these concerns.

\section{Some crucial technologies supporting future development of petroleum refining industry}

\subsection{High-efficiency heavy oil conversion technology}

Currently, oil resource use in China is still relatively limited because of the gap in light distillate yield between domestic and overseas producers of gasoline and diesel. The domestic light oil yield is around $75 \%$ on average, while the more advanced overseas operations achieve a light distillate yield of more than $80 \%$. The key for increasing the light oil yield is to convert more heavy oils (atmospheric residue-AR or vacuum residue-VR), which typically account for $40 \%-60 \%$ of crude feed, into light petroleum products. Considering China's apparent total oil consumption in 2010 of 455 million tons, a 1\% increase in light oil yield could result in an additional 1.8-2.7 million tons of light petroleum products used as gasoline and diesel. This would be equivalent to converting an additional 2.4-3.6 million tons of crude oil.

The most important technologies for processing heavy oil in the future include: (1) the residue hydrotreating technology (RHT), (2) the research institute of petroleum processing's (RIPP's) integrated combination process for residue hydroprocessing (RICP), (3) the integration of selective hydrogenation of fluid catalytic cracking gas oil (FGO) with selective catalytic cracking process (IHCC), and (4) the combination of superficial solvent deasphalting, hydrotreatment of deasphalted oil, and fluid catalytic cracking technologies.

\subsubsection{Residue hydrotreating technology}

The purpose of RHT is to provide on-spec feedstock to the fluid catalytic cracking (FCC) unit. Residue conversion into light distillates is primarily realized inside the FCC unit, which requires that the residue hydrotreating facilities provide qualified feedstock having fewer impurities and more suitable crackability for working over long operating cycles. To meet these objectives by developing RHT series catalysts (including the RG series guard catalysts, the demetallation catalyst RDM-2, and the desulfurization catalyst RMS-1), the RIPP has developed the asphaltene conversion catalyst RDM-2 with demetallation capability, followed by development of the novel RUF series hydrodemetallation catalysts and the novel hydrodesulfurization catalyst RMS-1B.

Based on catalyst performance, reaction kinetics, and catalyst deactivation modeling, the RIPP has developed a proprietary technique for grading residual hydrotreating catalysts that can raise the overall RHT effectiveness when using the above novel catalysts. For example, the RHT series catalysts applied on the commercial scale at Sinopec's Qilu Branch Company achieved an operating cycle of 16.5 months. This was 3 months longer than that realized by the reference catalyst, and the ser- vice life of the RHT series catalysts was extended by $22 \%$ [1]. Afterwards, the Chinese Petroleum Corporation, Taiwan, upon applying the RHT series catalysts, was able to run the residual hydrotreating unit for 10 months, which was 3 months longer than that achieved by similar overseas reference catalysts, and the service life of the RHT series catalysts was extended by more than $40 \%$. This resulted in significant economic benefits for the company.

Since the RHT series residual hydrotreating catalysts were first applied in commercial scale on the upflow reactor/residual desulfurization unit at the Qilu Petrochemical Branch Company in October 2002, there have been 16 successful commercial applications of these catalysts in 16 process units coupled with 4 other units under construction that plan to adopt the RHT technology.

\subsubsection{Residue hydrotreating integrated with catalytic cracking process}

The traditional residue hydrotreating-FCC combination technology processes hydrotreated tail oil in the FCC unit with the FCC heavy cycle oil (HCO) circulating inside the unit, representing a one-directional process scheme. Since the HCO contains a large amount of polynuclear aromatic hydrocarbons, recycling of this oil would lead to reduced light oil yield and increased coke and gas yields. If the hydrotreating unit runs on pure VR, it could not operate for long because of the extremely high viscosity of VR. However, if the unit runs on AR or on VR that is blended with vacuum gas oil (VGO), serving as a diluting oil, there would be insufficient supply of feedstock to the hydrotreating unit. In this case, the goal of maximizing high quality middle distillate oil could not be achieved.

Rather than circulating HCO inside the FCC unit, the RICP technology mixes this heavy cycle oil with VR to serve as part of the feedstock to the hydrotreating unit. With this technology, the hydrotreated product is routed back to the FCC unit for further processing so that the HCO can circulate along a large loop in the hydrotreating and FCC units, as shown in Fig. 1. Commercial operation of the RICP process at the Qilu Petrochemical Branch Company has demonstrated that the RICP technology has obvious advantages to both the residue hydrotreating unit and the FCC unit, resulting in remarkable economic benefits for the refinery $[2,3]$.

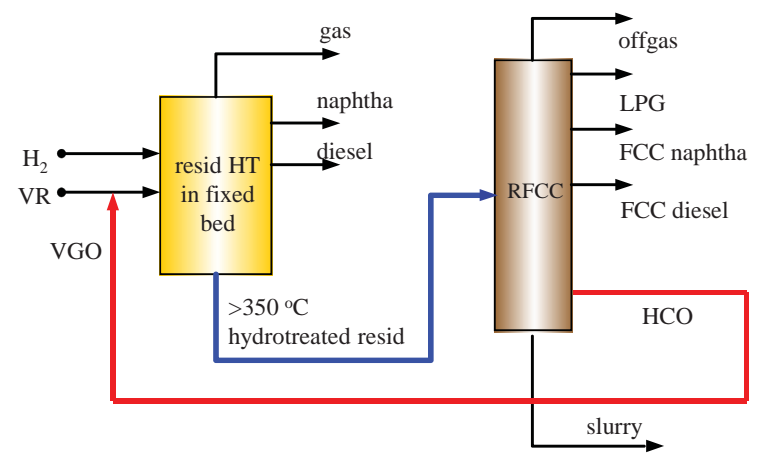

Fig. 1. Flow diagram of the residue hydrotreating integrated with the catalytic cracking process [3]. VR-Vacuum residual; LPG-Liquid petroleum gas. 
Table 1

Comparison between RICP and conventional process.

\begin{tabular}{lcccccr}
\hline \multirow{2}{*}{ Technology } & Ratio of hydrotreated resid & \multicolumn{3}{c}{ Product distribution (\%) } \\
\cline { 3 - 6 } & $(\%)$ & Off gas & LPG & Stabilized gasoline & Diesel & Slurry \\
Reference case & 72.60 & 2.14 & 13.53 & 39.13 & 32.97 & 3.54 \\
RICP & 76.44 & 2.02 & 13.40 & 40.72 & 33.28 & 2.45 \\
Difference & +3.84 & -0.12 & -0.13 & 1.60 & 0.30 & -1.09 \\
\hline
\end{tabular}

This technology has the following characteristics:

1. In comparison with the reference case, the residual hydrotreating unit has apparently enhanced the hydrodesulfurization (HDS), hydrodemetallization (HDM), and Conradson carbon residue removal reactions when operating on VR blended with HCO. This can remarkably reduce the viscosity of feedstock processed in the hydrotreating unit and improve the quality of the FCC feed. Meanwhile, HCO with high aromaticity can obviously improve the coke distribution on residual hydrotreating catalyst to enhance the overall efficiency of the catalyst.

2. Because hydrotreating of HCO has greatly improved the FCC feed quality, the light oil yield from the FCC unit can be substantially increased while the yield of slurry and coke is apparently reduced.

3. Recycling of HCO obtained from the FCC unit to the residue hydrotreating unit can help the residue hydrotreating unit reduce or eliminate its need for VGO, which functions as the diluting oil for VR. The result is that the hydrocracking unit, in processing this VGO stream, can manufacture more middle distillate oil, thereby improving the refinery's process flow diagram and enhancing overall economic benefits.

In May 2006, the Sinopec Qilu Branch Company began applying in commercial scale the RICP technology. The technical calibration tests conducted in September 2006 (Table 1) demonstrated that, compared with the conventional residual hydrotreating-FCC combination process, the RICP technology had several advantages when using HCO that accounted for only $6 \%$ of feed oil to the residual hydrotreating unit. These advantages included a better impurities removal rate during residual hydrotreating and a $3.84 \%$ increase in the proportion of hydrotreated residuum in the FCC feed. Meanwhile the dis-

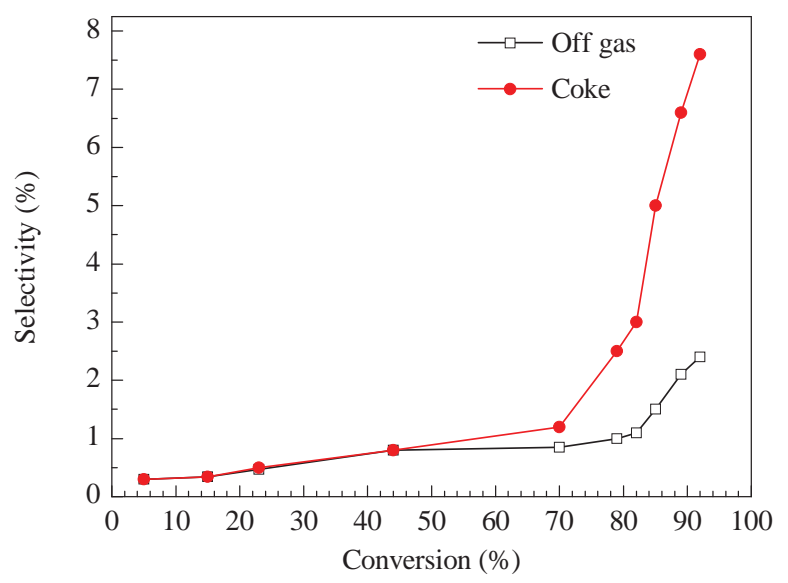

Fig. 2. Relationship between the yield of offgas and coke and the conversion rate [4]. tribution of FCC products was apparently improved, with the total yield of FCC naphtha and diesel fraction increasing by $1.90 \%$ and the yield of low-valued products (slurry and coke) decreasing by $1.65 \%$.

\subsubsection{Integration of selective hydrogenation of FGO with selective catalytic cracking for maximizing light oil yield}

The operating data for commercial FCC units and the test results for pilot FCC units demonstrate that the yield of offgas and coke obtained through conversion of residual in the FCC unit increases slowly with increasing residual conversion. However, the yield increases sharply after the residual conversion reaches $70 \%$ (Fig. 2), as seen during the conversion of paraffinic-base feedstock.

The RIPP, by taking into account the specific features of inferior feed oils, has analyzed in detail the reaction chemistry involved in the current catalytic cracking process. Based on a large number of experiments and tests, the RIPP has proposed integrating selective hydrotreating of FGO with the selective catalytic cracking (IHCC) process for maximizing light oil yield. The primary idea behind this process is to optimize offgas and coke selectivity by achieving a reasonable range of control over the single-pass conversion of FCC feed rather than pursuing maximum, once-through conversion of the residual. In this process, the unconverted heavy FGO is subjected to hydrotreating followed by appropriate catalytic cracking to maximize the yield of high add-value products. The core technology behind IHCC, as illustrated in Fig. 3, involves the following three steps:

1. Hydrogenation is accomplished with the selective catalytic cracking (HSCC) process.

2. The aromatics and resins in FGO obtained from the HSCC process are then subjected to selective hydrotreating for aromatics saturation. The goal of the FGO hydrotreating process (modeled after the HAR process) is to achieve saturation of paraffins, naphthenes, and aromatics (PNAs) and resins contained in FGO through selective hydrogenation while retaining, to the extent possible, the polynuclear naphthenic hydrocar-

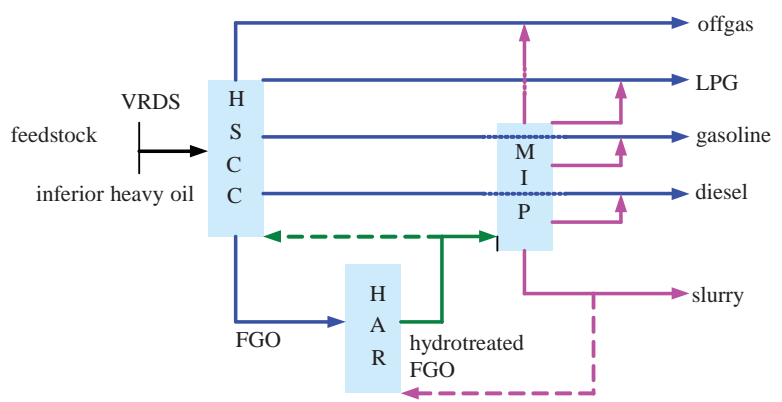

Fig. 3. Sketch of the IHCC process flow diagram [4]. 
Table 2

Differences between the pilot scale experimental results of IHCC and FCC.

\begin{tabular}{lcc}
\hline Technology type & IHCC & FCC \\
\hline Catalyst & Specialized catalyst & MLC-500 \\
Feed stock & $\begin{array}{l}\text { JingMen mixed } \\
\text { residuum }\end{array}$ & $\begin{array}{c}\text { JingMen mixed } \\
\text { residuum }\end{array}$ \\
Density & 0.9285 & 0.9285 \\
Carbon residue & 4.9 & 4.9 \\
Hydrogen content & 12.2 & 12.2 \\
Product distribution (\%) & & \\
Dry gas & 3.28 & 3.63 \\
Liquefied gas & 16.16 & 18.53 \\
Gasoline & 45.38 & 38.31 \\
Diesel oil & 25.47 & 21.02 \\
Heavy oil & 1.27 & 6.89 \\
Coke & 7.85 & 11.44 \\
Light oil yield & 70.85 & 59.33 \\
Total liquid yield & 87.01 & 77.86 \\
\hline
\end{tabular}

bons formed in the process.

3. The hydrotreated FGO, which can serve as the feedstock for operations such as the HSCC, FCC, and maximizing iso-paraffin (MIP) processes, is again subjected to catalytic cracking using the appropriate catalyst and process regime. This results in selective cracking of the alkane structural groups while retaining aromatic structural groups that can be treated by hydrosaturation of PNAs using the HAR process, thereby forming naphthenic hydrocarbons or monocyclic aromatics.

Thus, it is evident that on the feed oil molecular level, IHCC technology can enhance the coordination and integration of existing refining technologies. Pilot scale IHCC and FCC processes have demonstrated that the adoption of the IHCC process has resulted in apparently increased light oil and total liquid yields with significant reduction in coke yield, as shown in Table 2.

\subsubsection{Superficial solvent deasphalting-DAO hydrotreating-FCC technology}

Some grades of VR derived from imported sour crudes contain high nickel and vanadium contents and cannot be processed directly with the fixed-bed residue hydrotreating technology. An urgent issue concerns how to achieve in an economic and effective manner a maximum yield of clean automotive fuel from low-valued VR having a high sulfur and heavy

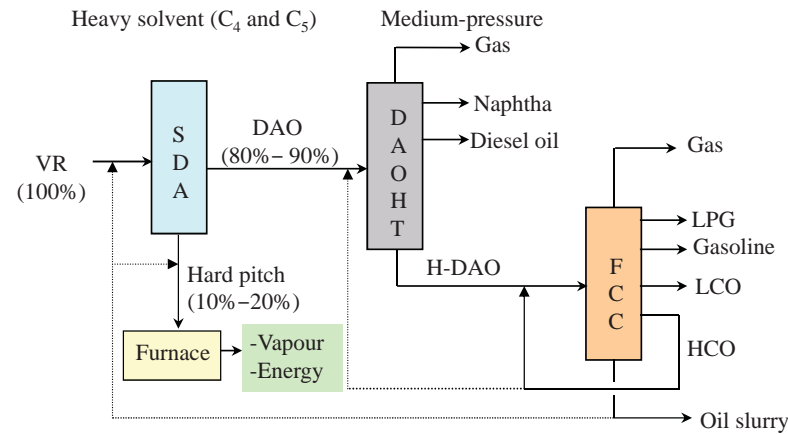

Fig. 4. Schematic flow diagram of SHF combination process [5]. metals content.

The superficial solvent deasphalting-DAO hydrotreating-FCC technology (SHF) developed by the RIPP is an effective means for processing inferior residuum with a high content of sulfur and heavy metals. Using heavy solvents (butane and pentane), the SHF technology can remove almost all asphaltenes and more than $70 \%$ of heavy metals from inferior vacuum residue while providing a high yield of deasphalted oil (DAO) in the range of $80 \%-90 \%$ [3]. The hydrotreated DAO is a premium FCC feedstock that can be used to manufacture clean gasoline with low sulfur and olefins contents. A schematic flow diagram of the SHF process is presented in Fig. 4.

The results of deasphalting of VR derived from Arabian light (AL) crude using normal pentane as the solvent are presented in Table 3. While the mass fraction of asphaltenes in DAO was reduced to less than $0.05 \%$ and the nickel and vanadium contents were also significantly reduced, the DAO yield reached 85.5\%.

The DAO was then subjected to pilot-scale hydrotreating tests, resulting in the product distributions and properties presented in Tables 4 and 5, respectively.

The density, viscosity, and Conradson carbon residue (CCR) values of hydrotreated DAO were apparently improved along with a remarkable reduction in sulfur, nitrogen, and metals contents. As a result, this hydrotreated DAO can serve as a premium FCC feedstock. The distributions and properties of major products formed during catalytic cracking of tail oil obtained during hydrotreating of AL-derived DAO are presented in Tables 6 and 7, respectively.

The pilot-scale catalytic cracking test of tail oil obtained during hydrotreating of DAO derived from AL resulted in a total yield of light hydrocarbons exceeding $83 \%$, and the sulfur content in FCC gasoline was low enough to meet the Euro III

Table 3

Pentane deasphalting of VR derived from Arabian light crude.

\begin{tabular}{lccc}
\hline \multirow{2}{*}{ Item } & $\begin{array}{c}\text { Vacuum residues } \\
\text { of saudi arabian } \\
\text { light crude oils }\end{array}$ & $\begin{array}{c}\text { Deasphalt- } \\
\text { ed oil }\end{array}$ & Asphalt \\
\hline Yield $(\%)$ & 100 & 85.5 & 14.5 \\
Viscosity $\left(100{ }^{\circ} \mathrm{C}, \mathrm{mm}^{2} / \mathrm{s}\right)$ & 498.8 & 117.3 & - \\
Conradson carbon residue (\%) & 18.7 & 11.5 & 61.2 \\
Density $\left(20^{\circ} \mathrm{C}, \mathrm{g} / \mathrm{cm}^{3}\right)$ & 1.001 & 0.9715 & 1.150 \\
$\mathrm{~S}(\%)$ & 4.04 & 3.89 & 5.92 \\
$\mathrm{Ni}(\mu \mathrm{g} / \mathrm{g})$ & 20.5 & 3.4 & 127 \\
$\mathrm{~V}(\mu \mathrm{g} / \mathrm{g})$ & 71.8 & 14.9 & 402 \\
$n$-Heptane insoluble $(\%)$ & 6.8 & $<0.05$ & - \\
Softening point $(\mathrm{R} \& \mathrm{~B})\left({ }^{\circ} \mathrm{C}\right)$ & - & - & 155 \\
\hline
\end{tabular}

Table 4

Distributions of products obtained from pilot-scale hydrotreating of DAO derived from AL.

\begin{tabular}{lc}
\hline Products & Distribution \\
\hline $\mathrm{H}_{2} \mathrm{~S}+\mathrm{NH}_{3}$ & 3.7 \\
$\mathrm{C} 1-\mathrm{C} 4$ & 0.5 \\
$\mathrm{C} 5-180^{\circ} \mathrm{C}$ & 1.0 \\
$180-350^{\circ} \mathrm{C}$ & 8.5 \\
$350{ }^{\circ} \mathrm{C}+$ & 87.4 \\
\hline
\end{tabular}

Technological conditions: raw 100 and hydrogen 1.1 in gross of input 101.1, (RG-10A/RG-10B)/RDM-1/RMS-1 Catalyst, $p\left(\mathrm{H}_{2}\right) 8.0 \mathrm{MPa}$, LHSV $0.5 \mathrm{~h}^{-1}$, reaction temperature $380^{\circ} \mathrm{C}, \mathrm{H}_{2} / \mathrm{Oil} 650 \mathrm{~V} / \mathrm{V}$. 
Table 5

Properties of products obtained from pilot-scale hydrotreating of DAO derived from AL.

\begin{tabular}{lcccccccc}
\hline Product & $\begin{array}{c}\text { Density } \\
\left(20^{\circ} \mathrm{C}, \mathrm{g} / \mathrm{cm}^{3}\right)\end{array}$ & $\begin{array}{c}\text { Viscosity } \\
\left(100{ }^{\circ} \mathrm{C}, \mathrm{mm}^{2} / \mathrm{s}\right)\end{array}$ & $\begin{array}{c}\text { Carbon } \\
\text { residue }(\%)\end{array}$ & $\mathrm{S}(\%)$ & $\mathrm{N}(\%)$ & $\begin{array}{c}\mathrm{Ni}(\mu \mathrm{g} / \mathrm{g}) \\
\mathrm{V}(\mu \mathrm{g} / \mathrm{g})\end{array}$ & $\begin{array}{c}\text { Condensation } \\
\text { point }\left({ }^{\circ} \mathrm{C}\right)\end{array}$ & $\begin{array}{c}\text { Cetane } \\
\text { number }\end{array}$ \\
\hline $\mathrm{DAO}$ & 0.9715 & 117.3 & 11.5 & 3.89 & - & 3.4 & 14.9 & - \\
$180-350{ }^{\circ} \mathrm{C}$ & 0.8800 & - & - & $<200 \mu \mathrm{g} / \mathrm{g}$ & $250 \mu \mathrm{g} / \mathrm{g}$ & - & - & - \\
$350{ }^{\circ} \mathrm{C}+$ & 0.9400 & 35 & 3.5 & 0.30 & 0.13 & $<1$ & $<1$ & -18 \\
\hline
\end{tabular}

Table 7

Properties of products obtained during FCC of tail oil formed upon hydrotreating of DAO derived from AL.

\begin{tabular}{lcccccc}
\hline Product & $\begin{array}{c}\text { Density } \\
\left(20^{\circ} \mathrm{C}, \mathrm{g} / \mathrm{cm}^{3}\right)\end{array}$ & $\begin{array}{c}\text { Sulfur } \\
(\mu \mathrm{g} / \mathrm{g})\end{array}$ & Alkene $(\%)$ & RON & MON & $\begin{array}{c}\text { Condensation point } \\
\left({ }^{\circ} \mathrm{C}\right)\end{array}$ \\
\hline FCC gasoline & 0.7498 & 25 & 25 & 90.1 & 79.8 & - \\
FCC diesel oil & 0.9452 & 0.20 & - & - & - & -39 \\
\hline
\end{tabular}

RON-Research octane number. MON-Motor octane number.

Table 8

Comparison of properties between pitch/water slurry fuel and other fuels [6].

\begin{tabular}{lccccc}
\hline Slurry & Raw material & Content $(\%)$ & Viscosity $\left(\mathrm{cP} 30^{\circ} \mathrm{C}\right)$ & Density $\left(\mathrm{g} / \mathrm{cm}^{3}\right)$ & Heat value $(\mathrm{Kcal} / \mathrm{kg})$ Mean diameter $(\mu \mathrm{m})$ \\
\hline Hard pitch-water slurry & hard pitch & $69 \pm 1$ & 1000 & 1.1 & 6660 \\
Coal-water slurry & coal & 70 & 1000 & 1.2 & 33.5 \\
Tar pitch-water slurry & tar pitch & $72 \pm 1$ & $<900$ & 1.01 & 53.8 \\
\hline
\end{tabular}

standard, Also, the test results included an apparently improved diesel quality that lends itself to further quality upgrading.

Because the key to successful applications of the SHF technology is finding proper outlets for hard pitch, this technology is especially suitable for refineries equipped with circulating fluidized bed boilers and for integrated gasification combined-cycle power plants that can handle hard pitch. The Japan Gas Company has developed technology for preparing a hard pitch/water slurry (Fig. 5) [6] with a calorific value slightly lower than the tar pitch/water slurry but apparently higher than the water/coal slurry (Table 8).

\subsection{Key technologies for production of clean fuel}

2.2.1 RIPP selective hydrodesulfurization technology (RSDS) [7]

To cope with an ever increasing demand for clean low-sulfur gasoline inside China, the hydrodesulfurization rate of FCC naphtha has been increased to $95 \%-98 \%$ from the original goal of $80 \%-90 \%$. Also, the target sulfur content in the fuel product has been reduced to $50 \mu \mathrm{g} / \mathrm{g}$, or to $10 \mu \mathrm{g} / \mathrm{g}$ with a reduced research octane number (RON) loss in gasoline. The

Table 6

Distributions of products obtained during FCC of tail oil formed upon hydrotreating of DAO derived from AL.

\begin{tabular}{lc}
\hline Product & Distribution (\%) \\
\hline Dry gas & 3.9 \\
Liquefied gas & 12.8 \\
Stable gasoline & 45.0 \\
Light diesel oil & 25.5 \\
Slurry oil & 5.0 \\
Coke & 7.3 \\
Lose & 0.5 \\
Total & 100.0 \\
Total light hydrocarbon yield & 83.3 \\
\hline
\end{tabular}

RIPP selective hydrodesulfurization (RSDS) technology is designed to minimize the olefins saturation rate during hydrodesulfurization reactions.

There are two options for achieving the low-sulfur content goal. First, by taking into account the different feedstocks and target products and by considering the distribution of sulfur compounds and olefins in FCC naphtha (with olefins mostly concentrated in the light naphtha fraction and sulfur compounds mostly distributed in the heavy naphtha fraction), the entire FCC naphtha must be separated into different fractions according to proper cut temperatures. Also, the heavy FCC naphtha fraction must be subjected to selective HDS, which can reduce to a considerable extent the saturation of olefins, as required to manufacture the target product. The second option is to conduct research on the development of selective HDS catalysts. The results of basic research have revealed that the selectivity of gasoline HDS catalyst (ratio of hydrodesulfurization rate to olefins saturation rate) is closely related to the structure of the active phase in the catalyst.

X-ray diffraction (XRD) analysis of the oxidized CoMo cata-

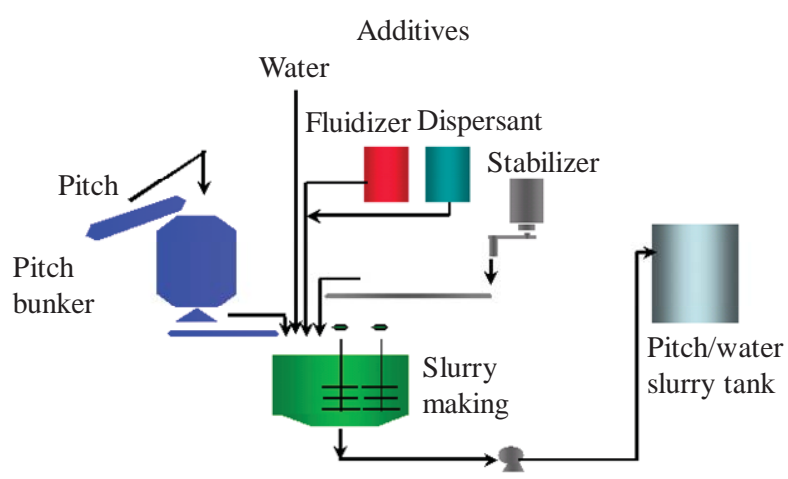

Fig. 5. Schematic diagram for the production of hard pitch-water slurry [6]. 


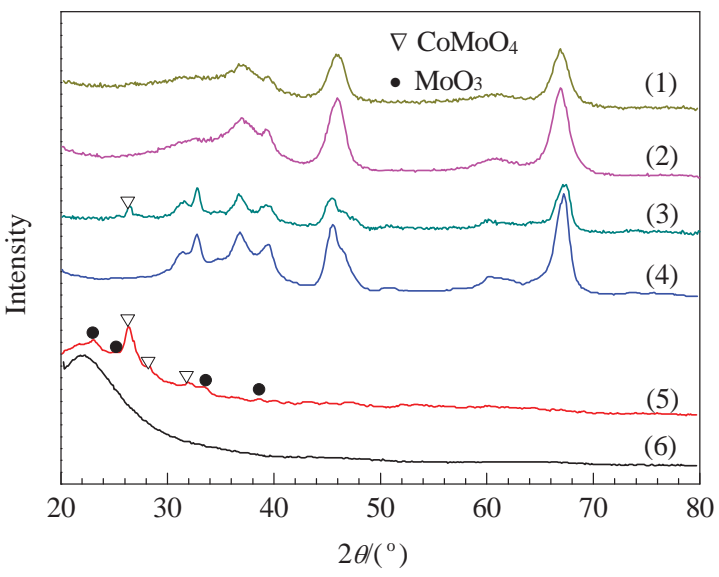

Fig. 6. XRD patterns of oxidized catalysts [7]. (1) CoMo-C/Support-1; (2) Support-1; (3) CoMo-C/Support-2; (4) Support-2; (5) CoMo-C/Support-3; (6) Support-3.

lysts on different supports has shown that when metals are weakly bound with the support, oxidized state precursors, predominantly consisting of aggregated $\mathrm{CoMoO}_{4}$ and $\mathrm{MoO}_{3}$ species, readily form (Fig. 6). During calcination of CoMo salt, loaded on support-2 and support-3, $\mathrm{CoMoO}_{4}$ and $\mathrm{MoO}_{3}$ formed, with the quantity of these compounds even more prevalent on support-3. Research has indicated that $\mathrm{CoMoO}_{4}$ and $\mathrm{MoO}_{3}$ species cannot be sulfurized to form the Co-Mo-S phase, resulting in lower HDS reaction activity and hydrodesulfurization/hydrogenation (HDS/HYD) selectivity. The selective hydrodesulfurization tests of model compounds in the micro-reactor indicated that the selectivity factor (ST) of these two sulfurized species was equal to 0.1 in each case, indicating a worse selectivity. (ST is the ratio of hydrodesulfurization rate to olefins saturation rate.) This is an important aspect of the relationship between the phase composition and the selectivity of the catalyst used in the selective HDS of FCC naphtha.

Meanwhile, the catalysts manufactured by different preparation methods were characterized by transmission electron microscopy, based on the lamellar crystal length of active phase (Co)MoS 2 . Tests indicated that with increasing lamellar crystal length, the HDS/HYD ST also increased [8,9], as shown in Fig. 7. However, the longer lamellar crystals can lead to a reduction in the number of total active sites, resulting in decreased HDS activity of the catalyst. This is a second important aspect of the relationship between the phase composition and selectivity of the catalyst for selective HDS of FCC naphtha.

Based on a study of the topology and structure of the sulfu-

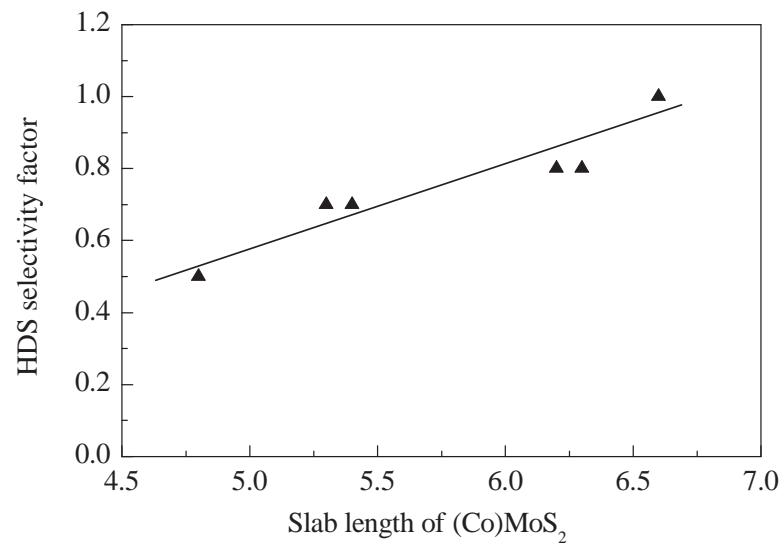

Fig. 7. Relationship between the size of the active phase and the selectivity of the hydrodesulfurization catalyst [7].

rized active phase of CoMo species loaded on different catalyst supports and on an investigation of their influence on the HDS/HYD ST, we established a selectively hydrodesulfurized active phase model for the loaded-type CoMo catalysts. $\mathrm{CoMoO}_{4}$ and $\mathrm{MoO}_{3}$ species are the precursors of the active phase that are responsible for low HDS activity and low HDS/HYD selectivity of the catalyst. The Co-Mo-S phase is the active phase that is conducive to high HDS activity and high HDS/HYD selectivity, whereas the angular location of the Co-Mo-S phase's lamellar crystals is beneficial to the HYD reaction, and their edge-side location is favorable for the HDS reaction. At the same reaction temperature, the HDS/HYD ST is proportional to the side/angle ratio of the active phase's lamellar crystals.

Compared with the performance of the first generation catalysts (the RSDS-1 series for selective hydrodesulfurization of FCC naphtha), the second generation catalysts (the RSDS-2 series for selective hydrodesulfurization of FCC naphtha) significantly reduce the saturation of olefins at the same sulfur removal rate. The result is satisfactory retention of the gasoline octane rating and a deeper desulfurization of gasoline, as shown in Table 9.

Operational data at the Shanghai petrochemical plant over a 280-day period indicate that gasoline with a sulfur content below $50 \mu \mathrm{g} / \mathrm{g}$ meets the requirements of the State IV emission standard, as shown in Fig. 8.

\subsubsection{Hydrogenation technology for production of ULSD [10].}

With environmental regulations becoming increasingly stringent, the specifications for transportation fuels become tighter every year. The main regulatory focus on diesel fuel

Table 9

Comparison of running results between RSDS-I and RSDS-II at the Shanghai Petrochemical plant.

\begin{tabular}{|c|c|c|c|c|c|c|}
\hline Technology & $\mathrm{S}(\mu \mathrm{g} / \mathrm{g})$ & Olefin $(\varphi \%)$ & RON/MON & Desulfurization rate (\%) & Loss of RON & Loss of AKI \\
\hline \multicolumn{7}{|c|}{ RSDS-I technology } \\
\hline Feedstock & 440 & 46.9 & $94.9 / 81.7$ & - & - & - \\
\hline Products & 36 & 35.3 & $93 / 80.6$ & 91.8 & 1.9 & 1.2 \\
\hline \multicolumn{7}{|c|}{ RSDS-II technology } \\
\hline Feedstock & 470 & 40.8 & $93.6 / 80.5$ & - & - & - \\
\hline Products & 34 & 39.7 & $93.0 / 80.6$ & 92.8 & 0.6 & 0.3 \\
\hline
\end{tabular}

AKI-Anti-knock index (often written on pumps as (RON + MON)/2). 


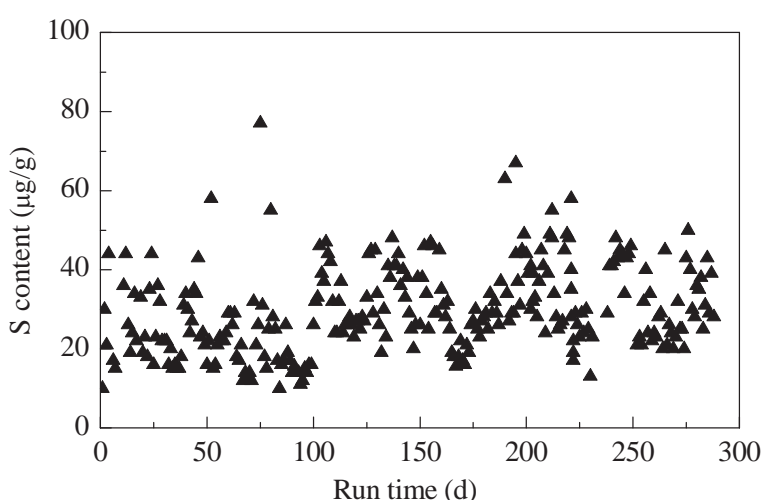

Fig. 8. Operational stability of RSDS-II technology at the Shanghai petrochemical plant.

quality is to significantly reduce the sulfur content.

To meet the demand for diesel fuel complying with the Euro IV and V standards, the RIPP recently developed hydrodesulfurization technology for the production of ultra-low-sulfur diesel fuel (ULSD) at a high space velocity (referred to the RTS technology). The design concept involves a first reaction zone that: (1) operates at a moderately high temperature and high space velocity, and (2) removes the most readily hydrotreated sulfur compounds and almost all nitrogen compounds while achieving partial saturation of polynuclear aromatics. Additionally, the design includes a second reaction zone that operates at a relatively low temperature and high space velocity, that completely removes the remnant sulfur compounds, and that achieves further hydrosaturation of polynuclear aromatics to deliver an almost transparent, colorless ULSD. Using high-sulfur straight-run diesel fraction as the feedstock (Table 10) and a space velocity that is $50 \%$ more than that adopted by conventional hydrotreating technology, the RTS technology can manufacture ULSD with a sulfur content less than $50 \mu \mathrm{g} / \mathrm{g}$ and $10 \mu \mathrm{g} / \mathrm{g}$ apiece. The ULDS produced by the RTS technology has a water-white color, and its other properties are presented in Table 11. The RTS commercial plant will begin operating in 2013.

\subsubsection{RS-1000 and RS-2000 catalysts for Ultra-deep HDS of diesel}

The key for reducing the sulfur content in diesel fuel to less than 50 and $10 \mu \mathrm{g} / \mathrm{g}$ is to remove 4,6-dimethyl dibenzothiophene (4,6-DMDBT) which is a sterically hindered condensed-ring thiophene. There are two routes for HDS in these compounds: the direct desulfurization (DDS) route and the HYD route [9]. The former route removes sulfur atoms through the direct cleavage of $\mathrm{C}-\mathrm{S}$ bonds, whereas in the latter route the aromatic rings achieve hydrosaturation prior to $\mathrm{C}-\mathrm{S}$ bonds cleavage.

Following many years of basic and applied fundamental research, the RIPP has been making a progress with respect to understanding the technical approaches for high-efficiency use of active metals. Furthermore, through uninterrupted optimization and integration of research achievements, the RIPP has successfully set up a next-generation advanced catalyst technology platform for maximizing active sites. Known as the MAS technology platform, this innovative technology has provided a solid technical foundation for the development of novel high-performance catalysts.

In recent years, catalyst preparation technology using complexing agents has become mainstream for manufacturing distillate oil hydrogenation catalysts, both in China and abroad. Complexing agents are effective for this purpose due to their ability to promote the formation of active phases for the hydrogenation reaction. At the beginning of this century, the RIPP was the first research organization within China to successfully use catalyst preparation technology based on the complexation method for the manufacture of a series of high-performance industrial hydrotreating catalysts, including the RS-1000 series of catalysts. Since then, the RIPP has been working constantly on improvements to catalyst preparation technology through complexation.

Catalyst preparation technologies using complexation in the MAS platform include the following:

1. Optimized and upgraded preparation technology.

2. Technology for adjusting and controlling the surface quality of the catalyst support to optimize the interaction between

Table 10

Properties of feedstocks used for producing ULSD by the RTS technology.

\begin{tabular}{|c|c|c|c|c|c|c|c|c|c|}
\hline \multirow[b]{2}{*}{ Feedstock } & \multirow{2}{*}{$\begin{array}{c}\text { Density } \\
\left(20^{\circ} \mathrm{C}, \mathrm{g} / \mathrm{cm}^{3}\right)\end{array}$} & \multirow{2}{*}{$\begin{array}{c}\text { Sulfur } \\
\text { content } \\
(\%)\end{array}$} & \multirow{2}{*}{$\begin{array}{c}\text { Nitrogen } \\
\text { content } \\
(\mu \mathrm{g} / \mathrm{g})\end{array}$} & \multirow{2}{*}{$\begin{array}{c}\text { Chroma (ASTM } \\
\text { D1500) }\end{array}$} & \multirow{2}{*}{$\begin{array}{l}\text { Cetane number } \\
\text { (ASTM D4737) }\end{array}$} & \multicolumn{4}{|c|}{ Boiling range (ASTM D86, $\left.{ }^{\circ} \mathrm{C}\right)$} \\
\hline & & & & & & $\begin{array}{c}\text { Initial boiling } \\
\text { point }\end{array}$ & $50 \%$ & $90 \%$ & $\begin{array}{c}\text { Final boiling } \\
\text { point }\end{array}$ \\
\hline Zhenhai straight-run diesel & 0.8388 & 0.78 & 155 & 0.6 & 54.5 & 193 & 283 & 347 & 377 \\
\hline Maoming straight-run diesel & 0.8514 & 1.50 & 100 & 0.6 & 56.8 & 206 & 313 & 364 & 379 \\
\hline Iran straight-run diesel & 0.8449 & 1.10 & 75 & 0.6 & 55.6 & 216 & 292 & 346 & 369 \\
\hline
\end{tabular}

Table 11

Properties of ULSD produced by the RTS technology.

\begin{tabular}{|c|c|c|c|c|c|c|c|c|c|c|}
\hline Feedstock & $\begin{array}{c}\mathrm{P}\left(\mathrm{H}_{2}\right) / \\
\mathrm{MPa}\end{array}$ & $\begin{array}{c}\text { Total } \\
\text { space } \\
\text { velocity } \\
\left(\mathrm{h}^{-1}\right)\end{array}$ & $\begin{array}{c}V\left(\mathrm{H}_{2}\right) / \\
V(\text { oil })\end{array}$ & $\begin{array}{l}\text { Density } \\
\left(20^{\circ} \mathrm{C},\right. \\
\left.\mathrm{g} / \mathrm{cm}^{3}\right)\end{array}$ & $\begin{array}{c}\text { Chroma } \\
\text { (ASTM } \\
\text { D1500) }\end{array}$ & $\begin{array}{c}\text { Sulfur } \\
\text { content } \\
(\mu \mathrm{g} / \mathrm{g})\end{array}$ & $\begin{array}{c}\text { Nitrogen } \\
\text { content } \\
(\mu \mathrm{g} / \mathrm{g})\end{array}$ & $\begin{array}{c}\text { Cetane } \\
\text { number } \\
\text { index } \\
\text { (ASTM } \\
\text { D4737) }\end{array}$ & $\begin{array}{l}\text { Initial boil- } \\
\text { ing point } \\
(50 \%)\end{array}$ & $\begin{array}{c}\text { Final boiling } \\
\text { point } \\
(90 \%)\end{array}$ \\
\hline Zhenhai straight-run diesel & 6.4 & 1.6 & 300 & 0.8162 & 0.1 & 8.6 & $<0.5$ & 60.2 & $169 / 271$ & $338 / 371$ \\
\hline Maoming straight-run diesel & 6.4 & 2.0 & 300 & 0.8248 & 0.1 & 9.5 & $<0.5$ & 61.5 & $184 / 287$ & $348 / 373$ \\
\hline Iran straight-run diesel & 6.4 & 2.5 & 300 & 0.8188 & 0.1 & 7.0 & $<0.5$ & 60.5 & $174 / 278$ & $337 / 364$ \\
\hline
\end{tabular}


metals and the support and to optimize the surface $\mathrm{pH}$ value of the support in an attempt to increase the sulfidation and dispersion of metals.

3. Moderate activation technology for adopting a process regime with reduced severity compared with the conventional activation process. (This serves as a technology package for catalyst preparation using complexation to control precisely the catalyst activation process and to fully implement the action of the complexing agent.)

4. Technology for precise matching of metals, which is based on demand for catalyst performance, can optimize synergism between metals on the atomic level, in an attempt to form the dominant structure of active phases.

Based on the design concept for maximizing active centers, and aided by the MAS technology platform, the RIPP is engaged in investigating novel catalysts and has successfully developed a new generation of catalyst (RS-2000) for ultra-deep HDS of diesel. The HDS RS-2000 catalyst has achieved high-efficiency use of active metals by: (1) adopting active components composed of three metals (Ni/Mo/W) with best synergistic effects, and (2) use of a high-performance support provided with optimized surface property adjustment, coupled with improved preparation technology using complexation and precisely controlled moderate activation technique.

The HDS RS-1000 catalyst is the RIPP's first-generation catalyst for ultra-deep desulfurization of diesel fuel. In contrast, the NiMo type HDS catalyst is more common overseas and holds a more advanced reputation.

The performance of two catalysts, RS-2000 and RS-1000, were compared using a $100 \mathrm{ml}$ reaction unit and the same Middle East straight-run (SR) diesel fraction as the feedstock. The properties of the feedstock are presented in Table 12, while the test results are shown in Table 13.

It can be seen from Table 13 that upon hydrotreating of the Middle East SR diesel fraction, the RS-2000 catalyst demonstrated a remarkably better desulfurization performance than the RS-1000 catalyst under the same process regime. The relative desulfurization activity of the RS-2000 catalyst reached $132 \%-258 \%$ of that achieved by the RS- 1000 catalyst. The deeper the desulfurization degree, the more obvious was the advantage to the RS-2000 catalyst. During the production of ULSD with a sulfur content of less than $10 \mu \mathrm{g} / \mathrm{g}$, the reaction temperature of the TS-200 catalyst was below that of the RS-1000 catalyst by over $15^{\circ} \mathrm{C}$.

Table 14 presents a comparison between the RS-2000 catalyst and the overseas reference catalyst on their catalytic activity for ultra-deep HDS of diesel. Test results indicate that when

Table 12

Properties of feedstock used in pilot evaluation tests.

\begin{tabular}{lc}
\hline Feedstock & Middle east straight-run diesel \\
\hline Density $\left(20^{\circ} \mathrm{C}, \mathrm{g} / \mathrm{cm}^{3}\right)$ & 0.8321 \\
Refractive index, $\mathrm{n}_{70} \mathrm{D}$ & 1.4658 \\
Sulfur content $(\%)$ & 0.97 \\
Nitrogen content $(\mu \mathrm{g} / \mathrm{g})$ & 97 \\
Initial boiling point & 188 \\
$50 \%$ recovered at & 277 \\
$95 \%$ recovered at & 338 \\
Final boiling point & 365 \\
\hline
\end{tabular}

Table 13

Comparison of activity between the RS-2000 and RS-1000 catalysts.

\begin{tabular}{lccc}
\hline Reaction temperature $\left({ }^{\circ} \mathrm{C}\right)$ & Base line & Base line+15 & Base line+30 \\
\hline Product sulfur content, $\mu \mathrm{g} / \mathrm{g}$ & & & \\
RS-1000 & 148 & 16 & 8.5 \\
RS-2000 & 98 & 7.0 & 2.0 \\
$\begin{array}{l}\text { Product nitrogen content, } \mu \mathrm{g} / \mathrm{g} \\
\text { RS-1000 }\end{array}$ & 0.6 & $<0.2$ & $<0.2$ \\
RS-2000 & $<0.2$ & $<0.2$ & $<0.2$ \\
Relative HDS activity (\%) & & & \\
RS-1000 & 100 & 100 & 100 \\
RS-2000 & 132 & 172 & 258 \\
\hline
\end{tabular}

Feedstock conditions: $p\left(\mathrm{H}_{2}\right) 6.4 \mathrm{MPa}$, LHSV $2.0 \mathrm{~h}^{-1}$.

the sulfur content of the product was reduced to $10 \mu \mathrm{g} / \mathrm{g}$, the reaction temperature required by the RS-2000 catalyst was lower than that required by the reference catalyst by $17{ }^{\circ} \mathrm{C}$, giving the RS-2000 catalyst a clear advantage.

It is evident that the RS-2000 catalyst has excellent ability for ultra-deep HDS of diesel, and its catalytic performance is much better than that of the RS-1000 and advanced-level reference catalysts.

\subsection{Technology for producing premium chemical feedstocks [2]}

Generally, a $1.0 \%$ increase in a nation's gross domestic product would lead to $0.5 \%$ increase in demand for refined products and a $1.0 \%$ increase in demand for chemical products. Therefore, as China's economy continues increasing at a fast pace, the deficit in light naphtha for chemical use will continue to grow. Since the beginning of the $21^{\text {st }}$ century, most grassroots petrochemical plants built in the Middle East use ethane as the petrochemical feedstock for obtaining high ethylene yield, albeit with a low propylene yield. However, market trends indicate that the market demand for propylene will surpass the world's ethylene market needs. While the cost of ethylene manufactured from ethane in the US and the Middle East is much less than that manufactured from naphtha, the production cost of propylene manufactured by refineries in China is apparently lower than that manufactured by petrochemical plants. Thus, to enhance the global competitiveness of China's petrochemical industry, it is urgent that a high priority be placed on technical developments for maximizing the propylene output from heavy feedstocks.

The critical technology for manufacturing premium chemical feedstocks at future refineries is Sinopec's hydroprocessing for maximum propylene yield of FCC process (SHMP). By optimizing the combination of hydrotreating and deep catalytic cracking technologies, SHMP can produce over $30 \%$ of propylene from VGO coupled with the byproducts ethylene, benzene, toluene, and xylene, with the result that the overall energy consumption of process units and average production cost of

Table 14

Comparison of Ultra-deep HDS activity between the RS-2000 catalyst and the overseas reference catalyst.

\begin{tabular}{lc}
\hline Catalyst & Temperature needed to produce ULSD $\left({ }^{\circ} \mathrm{C}\right)$ \\
\hline RS-2000 & Base line \\
RS-1000 & Base line +15 \\
Foreign reference catalyst & Base line +17 \\
\hline
\end{tabular}




\title{
Graphical Abstract
}

Chin. J. Catal., 2013, 34: 48-60 doi: 10.1016/S1872-2067(11)60508-1

\section{Some crucial technologies supporting development of petroleum refining industry in the future}

LI Dadong*

SINOPEC Research Institute of Petroleum Processing

The technologies of efficiently processing heavy oil and producing clean transportation fuel and high-quality chemical raw materials are very crucial support to the future petroleum refining industry. Some technologies with good prospects are cited.

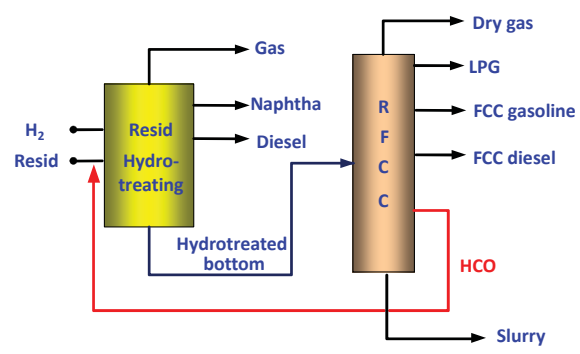

ethylene and propylene are apparently lower than those achieved by the naphtha steam cracking process.

The catalytic process for manufacturing propylene using the SHMP technology would encompass a number of process units, including: (1) the feedstock pretreatment unit (including the specialized catalysts and process), (2) the cracking unit (including the specialized catalysts, process, reactor, and special equipment), (3) the gas separation unit (including the gas separation process and equipment), (4) the aromatics extraction unit (including the hydrotreating of cracked gasoline and the liquid-liquid extraction technology), and (5) the utilities for the above-mentioned units. The SHMP technology for manufacturing propylene is a typical example of the organic integration of new catalytic materials, novel catalysts, and new catalytic processes, where of the success of every reaction process can be ascribed to the achievements of innovative catalytic technology.

\section{Conclusions}

The primary challenge facing the petroleum refining industry of China is the production of cleaner fuels and premium chemical feedstocks. To increase light distillate oil yield, upgrade the quality of automotive fuels, and produce more chemical feedstocks, high-efficiency catalysts should be tailored to cope with the specific features of crude slates and petroleum fractions. This is necessary to optimize the process regime and to develop crucial technology packages so that the future requirements of the petroleum refining industry can be met. Technologies such as RHT, RICP, IHCC, SHF, RSDS, RTS, RS-2000, and SHMP, which have been developed to meet the needs of China's petroleum refining industry and fulfill the demands of economic development, have gained international recognition as the principal processes for future refinery operations.

\section{References}

[1] Hu W J, Sun zh G. Petrol Process Petrochem (胡文景, 孙振光. 石油 炼制与化工), 2005, 36(7): 7

[2] Li D D. Acta Petrol Sin (Petrol Process Sec) (李大东. 石油学报(石油 加工)), 2005, 21(3): 17

[3] Sinopec Qilu Branch Company. Summary on the Second Technical Calibration and Long-Cycle Operation of RICP Technology Commercial Test (中国石化齐鲁分公司. 渣油加氢一重油催化裂化双 向组合技术RICP工业应用试验第二次技术标定及长周期运转总 结), 2007

[4] Xu Y H, Dai L S, Long J, Nie H. Petrol Process Petrochem (许友好, 戴 立顺, 龙军, 聂红. 石油炼制与化工), 2011, 42(3): 8

[5] Dai L S, Li D D, Shi Y H, Wang Z J. Petrol Process Petrochem (戴立顺, 李大东, 石亚华, 王子军. 石油炼制与化工), 2005, 36(3): 1

[6] Shigeki Nagamatsu. Heavy Oil Upgrading Technologies Coupled with Solvent Deasphalting Process. 2007 Proceedings of China-Japan-Korea Petroleum Congress, Tokyo

[7] Li M F, Xi Y B, Pan G C, Nie H. Petrol Process Petrochem (李明丰, 习 远兵, 潘光成, 聂红. 石油炼制与化工), 2010, 41(5): 1

[8] Li M F, Li H F, Jiang F, Chu Y, Nie H. Catal Today, 2010, 149: 35

[9] He M Y. The Green Chemistry on Petroleum Refining and Basic Organic Chemicals Synthesis. Beijing: SINOPEC Press (何鸣元. 石 油炼制和基本有机化学品合成的绿色化学. 北京: 中国石化出版 社), 2006. 174

[10] Ding L, Gao X D, Nie H, Wang Zh. Petrol Process Petrochem (丁否, 高晓冬, 聂红, 王哲. 石油炼制与化工), 2011, 42(6): 23

\section{支撑末来炼油工业发展的若干关键技术}

\author{
李大东* \\ 中国石化石油化工科学研究院, 北京100083
}

\begin{abstract}
摘要: 概述了未来炼油厂主要任务中关键技术的特点和使用效果. (1)提高轻质油收率, 关键在于重油的高效转化, 关键技术包括 渣油加氢技术、重油加氢与催化裂化双向组合技术、多产轻质油的催化裂化蜡油选择性加氢工艺与选择性催化裂化工艺集成技 术、浅度溶剂脱沥青-脱沥青油加氢处理-催化裂化技术; (2)生产清洁燃料, 主要是生产要求越来越高的清洁汽油和柴油, 关键技术 有汽油选择性加氢脱硫技术、柴油超深度加氢脱硫技术、柴油超深度加氢脱硫催化剂; (3)生产优质化工原料, 关键技术主要是催 化丙烯技术.
\end{abstract}

关键词: 渣油; 沥青质; 汽油; 柴油; 催化加氢; 催化裂化; 丙烯 
收稿日期: 2012-11-20. 接受日期: 2012-12-30. 出版日期: 2013-01-20.

*通讯联系人. 电话：(010)82368984; 传真：(010)62311290; 电子信箱：lidadong.ripp@ @inopec.com 本文的英文电子版由Elsevier出版社在ScienceDirect上出版(http://www.sciencedirect.com/science/journal/18722067).

\section{1. 前言}

世界生产的原油中重质油、含硫(高硫)油的比例越 来越大, 原油劣质化趋势越来越严重. 1996年, 全球生产 的原油中高硫和含硫原油占 $57.0 \%$, 重质原油占 $11.1 \%$, 至2010年分别增加到 $75.0 \%$ 和 $15.6 \%$. 从资源的角度来 看, 今后, 包括中国在内的各国炼油厂将不得不炼制更 多的劣质原油.

环保法规日益严格, 油品升级步伐加快. 2008年3月 1 日, 北京执行硫含量 $50 \mu \mathrm{g} / \mathrm{g}$ 以下的相当于欧IV的京标 IV 排放标准, 其它地区执行相当于欧II排放标准; 2010 年在上海、广州执行类似欧IV的排放标准, 其它地区执 行欧 III排放标准. 北京2012年5月执行京标 V排放标准, 车用汽柴油硫含量小于 $10 \mu \mathrm{g} / \mathrm{g}$. 未来市场的车用燃料 趋于 “超低硫”, 例如满足欧 $\mathrm{V}$ 排放标准, 要求硫含量 10 $\mu \mathrm{g} / \mathrm{g}$ 以下, 趋于 “无硫” . 不能满足排放标准的燃料将 无法进入市场.

在原油品质越来越差的情况下, 一方面要尽量提高 轻质油品的收率, 另一方面要满足日益严格的环保法规, 我国炼油企业面临着前所未有的严峻挑战. 因此, 必须 加强技术创新, 积极开发支撑炼油厂发展的关键技术.

\section{2. 支撑未来炼油工业发展的若干关键技术}

\section{1. 高效重油转化技术}

目前, 国内对石油资源的利用率仍处于相对偏低水 平, 汽柴油等轻质油收率平均在 $75 \%$ 左右, 而国外为 $80 \%$ 以上. 提高炼油轻质油收率的关键在于将占原油 40\% 60\%的重油(常压渣油或减压渣油)更多地转化为 轻质油品. 按2010年全年原油表观消费量4.55亿吨计算, 如果从重油中获得的轻质油品收率提高 $1 \%$, 将可增产 80 270万吨汽柴油等轻质石油产品, 相当于节省原油 240 360万吨.

未来加工重油的关键技术包括渣油加氢技术、重油 加氢与催化裂化双向组合技术、多产轻质油的FGO选择 性加氢工艺与选择性催化裂化工艺集成技术、浅度溶剂 脱沥青-脱沥青油加氢处理-催化裂化技术.

\subsection{1. 渣油加氢技术(RHT)}

渣油加氢的目的就是为催化裂化提供合格原料, 而 渣油轻质化主要在催化裂化单元进行, 因此催化裂化单
元要求重油加氢能够更长周期、更稳定地提供杂质含量 更低、更易裂化的优质原料. 为此, 石油化工科学研究院 (以下简称RIPP) 在开发了 RG系列保护剂、RDM-2脱金属 催化剂、RMS-1脱硫剂等RHT系列催化剂基础上, 为强 化沥青质转化和脱杂质能力, 先后开发了兼顾脱金属性 能的沥青质转化催化剂RDM-2B, 新型加氢脱金属催化 剂RUF系列以及新型加氢脱硫催化剂RMS-1B.

基于催化剂性能及反应动力学和催化剂失活模型, RIPP建立了渣油加氢催化剂级配专有技术, 配合上述新 型催化剂, 提高了渣油加氢技术整体水平. 例如, RHT系 列催化剂在中国石化齐鲁分公司工业应用装置运转周 期为 16.5 月, 比参比剂多 3 月, 寿命延长 $22 \%{ }^{[1]}$. 此后台湾 中油公司使用RHT系列催化剂, 重油加氢装置运转时间 达10月, 比国外同类型催化剂多3月, 运转周期延长 $40 \%$, 经济效益明显.

自2002年10月, RHT系列渣油加氢催化剂在齐鲁分 公司UFR/VRDS装置上首次工业应用以来, 目前已累计 有16次工业应用业绩, 另有4套在建装置采用RHT技术.

\subsection{2. 提高轻质油收率的重油加氢与催化裂化双向组 合技术(RICP)}

传统的渣油加氢一催化裂化组合工艺是催化裂化 装置加工渣油加氢尾油, 而催化裂化装置的回炼油自身 循环, 这是一个单向组合工艺. 由于催化裂化回炼油含 有大量多环芳烃, 自身回炼将会造成轻油收率降低, 生 焦量和干气量增加. 而对渣油加氢来说, 如果加工的是 纯减渣, 因粘度过高装置难以长期运转; 如果采用常压 渣油为原料, 或者以减压蜡油掺入到减渣中作为稀释油, 则会造成加氢裂化原料不足, 无法达到多产优质中间馏 分油的目的.

RICP技术将原来的催化裂化回炼油自身循环, 改为 先与渣油加氢原料混合, 作为渣油加氢处理进料的一部 分, 一起加氢后再回到催化裂化装置进行加工, 即催化 裂化回炼油在加氢装置与催化裂化装置间进行大循环 操作, 如图1所示. 齐鲁石化分公司工业运转结果表明, RICP技术对渣油加氢和催化裂化装置都带来明显的益 处, 能使炼油厂获得更大的经济效益 ${ }^{[2,3]}$ :

(1)对于渣油加氢装置, 与参比方案相比, 掺入催化 裂化回炼油后, 渣油加氢进料粘度大幅度降低, 渣油加 氢脱硫、脱金属和脱残炭等反应速度显著提高, 改善了 
催化裂化进料质量. 同时高芳香性的回炼油可以显著改 善渣油加氢催化剂上的积炭分布, 提高了渣油加氢催化 剂整体使用效率.

(2)对于催化裂化装置, 回炼油的加氢使得原料性质 明显改善, 因此轻质油收率较大幅度提高, 油浆和焦炭 产率显著降低.

(3)催化裂化回炼油循环至渣油加氢装置, 可以使渣 油加氢装置不再需要或者减少直馏蜡油 (VGO)作为减 压渣油的稀释油, 而让加氢裂化装置加工VGO生产更多 的中间馏分油, 从而进一步优化炼油厂加工流程和整体 效益.

2006年5月, RICP技术开始在中国石化齐鲁分公司 工业应用, 同年9月的技术标定结果(见表1)表明, 与常规 重油加氢与催化裂化组合工艺相比, 在重循环油(HCO) 仅占重油加氢装置进料量 $6 \%$ 条件下, RICP 技术促进了 重油加氢装置杂质脱除率, 并且使催化裂化装置加工加 氢重油的比例提高 $3.84 \%$, 同时产品分布明显改善, 汽油 和柴油总收率提高了 $1.90 \%$, 低价值产物(油浆和焦炭)收 率降低了 $1.65 \%$.

\subsection{3. 多产轻质油的FGO选择性加氢工艺与选择性催 化裂化工艺集成技术(IHCC)}

催化裂化工业装置的生产数据和中型催化裂化试 验结果表明, 重质原料油在催化裂化装置上转化生成的 干气和焦炭产率随转化率的增加而缓慢增加; 当转化率 达到 $70 \%$ 后, 干气和焦炭产率随转化率的增加而急剧增 加(见图2), 尤其是非石蜡基原料转化 ${ }^{[4]}$.

针对劣质原料油的特点, RIPP 对目前催化裂化过 程的反应化学进行了认真总结和分析, 在大量试验基础 上, 提出了多产轻质油的 $\mathrm{FGO}$ 选择性加氢处理工艺与 选择性催化裂化(缓和催化裂化)工艺集成技术(IHCC)的 构思. 其主要思路是对重质原料油不再追求其单程转化 率最高, 而是控制它在合理的范围, 使干气和焦炭选择 性最佳, 未转化的FGO经加氢处理后, 再采取适当的催 化裂化技术加工, 从而获得高价值产品收率最大化. 该 工艺的核心技术包括三部分 (见图3): (1)选择性催化裂 化工艺(HSCC); (2)HSCC工艺生产的FGO中芳烃和胶 质经选择性加氢处理工艺进行芳烃饱和, FGO加氢处理 工艺(HAR工艺)的目标是通过开发多环芳烃和胶质选择 性加氢技术, 饱和 FGO 中多环芳烃和胶质生成多环烷 烃, 同时尽可能地保留所生成的多环环烷烃; (3)加氢后 的FGO作为 HSCC, FCC或多产异构烷烃的催化裂化工 艺(MIP)的原料, 采用适宜的催化剂和工艺条件, 进行再
次催化裂化反应, 从而实现催化裂化反应只是选择性地 裂解烷烃结构基团, 而留下芳烃结构基团由HAR工艺对 其多环芳环进行加氢饱和成为环烷烃或单环芳烃. 由此 可见, IHCC工艺集成技术是从原料油分子结构水平上 强化现有的炼油技术协同和整合. IHCC 与FCC中试结 果表明, 采用IHCC过程, 轻质油收率和总液收明显提高, 而焦炭产率大幅度降低(见表 2).

\subsection{4. 浅度溶剂脱沥青-脱沥青油加氢处理-催化裂化 技术(SHF)}

我国进口的含硫原油中某些减压渣油 $\mathrm{Ni}, \mathrm{V}$ 等金属 含量很高, 难以直接采用固定床渣油加氢技术加工. 如 何采用经济有效的手段从这些低价值的减压渣油中最 大限度地生产车用清洁燃料是需解决的一个难题.

RIPP开发的SHF技术是加工高硫、高金属含量劣质 渣油的有效途径. SHF技术利用重溶剂(丁烷和戊烷) 脱 除劣质渣油中的几乎全部沥青质和 $70 \%$ 以上的金属, 而 得到的脱沥青油(DAO) 收率较高 ${ }^{[5]}$, 一般为 80\% 90\%. 加氢后的DAO是优质的FCC原料, 可直接生产低硫、低 烯烃的清洁汽油. SHF技术流程见图4.

以沙特轻质油减压渣油为例, 采用正戊烷为溶剂脱 沥青, 中试结果见表3. 可以看出, DAO中沥青质含量为 0.05\%以下, Ni, V含量大幅度降低, DAO收率为 $85.5 \%$.

将上述DAO进行中型加氢处理试验, 产品分布及产 品性质见表4和表 5.

$\mathrm{DAO}$ 经过加氢处理后, 密度、粘度、残炭等性质明 显改善, 硫、氮和金属含量大幅度降低, 是优质的催化裂 化原料. 沙特轻质油DAO加氢处理尾油经催化裂化后, 产品分布和主要产品性质见表6和表7.

以沙特轻质油DAO加氢处理尾油为原料进行催化 裂化中型试验, 总轻烃收率超过 $83 \%$, 汽油硫含量达到 欧III标准, 柴油性质明显地改善, 为下一步改质创造了 条件.

SHF技术应用的关键在于解决硬沥青的出路问题, 因此该技术特别适合建有循环流化床锅炉 (CFB)、汽电 一体化(IGCC)、燃料发电厂等可处理硬沥青的炼油厂. 日本日挥公司 $(\mathrm{JGC})$ 开发了用硬沥青制备硬沥青水浆燃 料的技术(见图 5) ${ }^{[6]}$, 硬沥青水浆的热值略低于焦油沥青 水浆, 但明显高于水煤浆(见表 8).

\section{2. 清洁燃料生产关键技术}

\subsection{1. 汽油选择性加氢脱硫技术(RSDS $)^{[7]}$}

随着国内对清洁低硫汽油产品需求不断提高, 要求 催化裂化汽油选择性加氢脱硫(HDS)技术的脱硫率的要 
求从原来的 $80 \%$ \% $0 \%$ 提高到 $95 \%$ \% $98 \%$, 产品目标硫含 量要求小于 $50 \mu \mathrm{g} / \mathrm{g}$ 或 $10 \mu \mathrm{g} / \mathrm{g}$, 并且 RON损失需进一步降 低. RIPP开发成功的催化裂化汽油选择性加氢脱硫 RSDS技术, 其出发点是如何在加氢脱硫的同时, 尽可能 少地饱和烯烃. 解决方法有两个: 一是根据催化裂化汽 油硫、烯烃的分布特点, (烯烃主要集中分布在轻馏分中; 硫主要集中分布在重馏分中), 针对不同的原料和目标 产品, 采用适当的切割点对全馏分FCC汽油进行切割, 对FCC重馏分进行选择性加氢脱硫, 从而在很大程度上 减少烯烃饱和; 二是研发选择性加氢脱硫催化剂. 基础 研究表明, 汽油加氢脱硫催化剂的选择性(脱硫率/烯烃 饱和率比值)同活性相结构有密切联系.

通过用不同载体制备的 $\mathrm{CoMo}$ 氧化态催化剂进行 $\mathrm{X}$ 射线衍射(XRD) 表征分析, 发现当金属与载体具有较弱 结合力时, 容易生成以 $\mathrm{CoMoO}_{4}, \mathrm{MoO}_{3}$ 为主要聚集态物 种的氧化态前驱体, 如图6所示. 载体-2 和载体-3 上负载 $\mathrm{CoMo}$ 金属盐物种后, 经焙烧均有一定量的 $\mathrm{CoMoO}_{4}$, $\mathrm{MoO}_{3}$ 生成, 尤以载体-3为甚. 研究发现, $\mathrm{CoMoO}_{4}, \mathrm{MoO}_{3}$ 物种不能硫化形成Co-Mo-S相, 其对应的HDS 反应活性 和HDS/HYD选择性较差. 采用模型化合物的选择性加 氢脱硫微反试验结果表明, 这两类物种硫化后加氢脱硫/ 烯烃饱和选择性因子 ST均为 0.1 , 意味着选择性差. 这是 催化裂化汽油选择性加氢脱硫催化剂相态组成与选择 性关系的一个方面.

同时, 采用透射电镜(TEM) 表征不同方法制备的催 化剂中 $(\mathrm{Co}) \mathrm{MoS}_{2}$ 活性相片晶的长度. 发现随着活性相 片晶尺寸的增大, 其HDS/HYD选择性因子 ST提高 ${ }^{[8,9]}$, 如图7所示; 但较长的片晶会导致总活性位数量的减少, 引起 HDS活性的下降. 这是催化裂化汽油选择性加氢 脱硫催化剂相态组成与选择性关系的第二个方面.

通过对不同载体上负载CoMo催化剂硫化态活性相 形貌结构及其对HDS/HYD选择性因子ST影响的研究, 建立了负载型 $\mathrm{CoMo}$ 催化剂上的选择性加氢脱硫活性相 模型. $\mathrm{CoMoO}_{4}$ 和 $\mathrm{MoO}_{3}$ 物种是形成低 HDS 活性和低 HDS/HYD选择性的活性相前驱物种, Co-Mo-S 相是高 HDS 活性和高HDS/HYD选择性的活性相; Co-Mo-S相 片晶的角位有利于HYD反应, 棱边位有利于HDS 反应. 在相同的反应温度下, HDS/HYD选择性因子ST与活性 相片晶的棱角比成正比关系.

在此基础上开发的第二代催化裂化汽油选择性加 氢脱硫催化剂RSDS-2系列与第一代催化裂化汽油选择 性加氢脱硫催化剂RSDS-1相比, 相同脱硫率下, 烯烃饱
和率可以大幅度降低, 从而保证在更深度脱硫情况下, 仍能较好保留汽油辛烷值(见表9).

上海石化RSDS-II装置运转280天结果表明, 汽油产 品硫含量低于 $50 \mu \mathrm{g} / \mathrm{g}$, 满足国IV排放标准要求(见图 8).

\subsection{2. 柴油超深度加氢脱硫技术 $(\mathbf{R T S})^{[10]}$}

随着环保条例要求越来越严, 运输燃料的规格也变 得越来越严格. 对柴油来说, 最主要的是硫含量显著地 减少.

针对生产欧IV和欧 $V$ 柴油的需要, 石科院最新开发 了高空速RTS技术, 其设计思路是: 第一反应区为适度 高温、高空速反应区, 用于完成大部分易脱硫硫化物的 脱硫和几乎全部氮化物的脱除、多环芳烃部分饱和; 第 二反应区为低温、高空速反应区, 实现剩余硫化物的彻 底脱除和多环芳烃的进一步加氢饱和, 得到颜色近水白 的超低硫柴油. 对以高硫直馏柴油为主的原料(表10), 采用 RTS 技术可在较常规加氢精制工艺高50\%以上的 空速下生产出硫含量小于 50 和 $10 \mu \mathrm{g} / \mathrm{g}$ 的超低硫柴油产 品, RTS技术生产的柴油产品颜色水白. 表11是采用 RTS技术生产的超低硫柴油的性质.

2013年采用RTS技术建设的工业装置将开工.

\subsection{3. 柴油超深度加氢脱硫催化剂RS-1000和RS-2000}

将柴油中的硫含量降至 50 和小于 $10 \mu \mathrm{g} / \mathrm{g}$ 以下, 关键 在于脱除以4,6-二甲基二苯并噻吩(4,6-DMDBT) 为代表 的稠环位阻噻吩类硫化物. 对于稠环位阻噻吩类硫化物 的加氢脱硫反应, 一般认为主要有直接脱硫(DDS)和加 氢脱硫(HYD) 两条途径 ${ }^{[9]}$ : 前者直接发生 C-S 键断裂反 应使硫原子被脱除; 后者则包括首先进行硫原子相邻芳 环的加氢饱和, 之后再发生C-S键的断裂反应.

经过多年的基础研究和应用基础研究, RIPP在如何 实现活性金属高效利用的技术途径方面取得了一系列 显著的进展, 通过不断优化和整合这些研究成果, 最终 成功构建了实现活性中心数量最大化的新一代先进催 化剂技术平台-MAS技术平台, 从而为新型高性能催化 剂的开发提供了坚实的技术基础.

由于可以有效地促进加氢活性相的生成, 络合制备 技术近年来已经成为国内外制备馏分油加氢催化剂的 主流技术. 自本世纪初RIPP率先在国内将络合制备技 术应用于RS-1000等一系列高性能工业加氢催化剂的制 备, 并获得成功. 此后, RIPP继续对络合制备技术进行 改进和完善, 进一步提高了络合制备技术的水平. MAS 平台所包含的络合制备技术组合为: 经过优化升级的络 合制备技术; 载体表面性质调控技术, 系指利用载体改 
性手段对载体表面性质进行调控, 以优化金属与载体间 的相互作用和载体表面酸碱性质, 提高金属硫化度和分 散度; 缓和活化技术, 即在催化剂活化阶段采用苛刻度 低于常规活化的工艺条件, 是与络合制备技术相配套的 技术, 目的在于精细控制催化剂的活化过程, 最大限度 地发挥络合剂的作用; 金属精确匹配技术, 系指根据对 催化剂的性能要求, 从原子水平上进行不同活性金属间 的精确匹配, 以获得金属间最佳的协同效果, 最大量地 生成活性相结构.

根据活性中心数量最大化的设计理念, 以MAS技术 平台为支撑, RIPP开展了新型催化剂的研制工作, 成功 开发了新一代柴油超深度加氢脱硫催化剂RS-2000. RS-2000采用具有最佳金属佳协同效应的Ni-Mo-W三金 属活性组分和表面性质优化调控的高性能载体, 配合以 改进的络合制备技术和精细控制的缓和活化技术, 实现 了活性金属的高效利用.

RS-1000是RIPP开发的第一代柴油超深度加氢脱硫 催化剂, 国外参比剂则是代表同领域国际先进水平的 NiMo型超深度加氢脱硫催化剂.

在 $100 \mathrm{ml}$ 装置上, 以同一种中东直柴为原料, 对 RS-2000 和 RS-1000 催化剂进行了对比评价, 原料油性 质和试验结果分别见表12和表13.

由表12可见, 在相同工艺条件下进行中东直柴的加 氢精制, RS-2000催化剂脱硫性能明显优于 RS-1000. 以 相对活性进行比较, RS-2000催化剂的脱硫活性达到 RS-1000催化剂的132\% 258\%. 脱硫深度越深, RS-2000 的活性优势越明显. 生产硫含量小于 $10 \mu \mathrm{g} / \mathrm{g}$ 超低硫柴 油时, RS-2000的反应温度比 RS-1000的低 $15^{\circ} \mathrm{C}$ 以上.

可见, RS-2000催化剂具有优异的柴油超深度脱硫 性能, 显著优于RS-1000和国外参比剂, 达到了同类催化 剂的国际先进水平.

\section{3. 生产优质化工原料的技术 ${ }^{[2]}$}

$\mathrm{GDP}$ 每增长 $1 \%$, 则炼油增长 $0.5 \%$, 化工增长 $1.0 \%$. 因此, 随着我国经济快速发展, 化工轻油相对短缺的问
题将更加突出, 而进入 21 世纪以来, 新的石油化工厂大 部分建立在中东, 这些石化厂的原料是乙烷, 其乙烯收 率高, 而丙烯收率很低, 但世界市场的发展趋势是丙烯 市场需求增长高于对乙烯需求的增长. 特别是中东和美 国以乙烷为原料生产的乙烯成本远远低于以石脑油为 原料的成本; 另一方面, 在我国炼油厂生产的丙烯成本 又明显低于石化厂丙烯的成本. 因此, 为使我国石化工 业更具有全球竞争力, 必须迅速加强从重质原料中生产 最大量丙烯的技术开发.

未来炼油厂生产优质化工原料所需要的关键技术 是催化丙烯技术 $(\mathrm{SHMP})^{[1]}$, 其总体目标是, 以 $\mathrm{VGO}$ 等为 原料, 通过加氢处理与催化裂解技术优化组合, 使丙烯 产率达到 $30 \%$ 以上, 同时副产乙烯和BTX, 装置能耗以 及丙烯和乙烯平均生产成本明显优于石脑油蒸汽裂解.

在SHMP催化丙烯技术中, 涉及的主要单元有原料 加氢预处理单元(包括专用催化剂、工艺); 裂解单元(包 括专用催化剂、工艺、反应器、专用设备等); 气体分离 单元(包括分离工艺、设备等); 芳烃抽提单元 (包括裂解 汽油的加氢处理、液-液抽提等), 以及上述各单元的集 成. SHMP催化丙烯技术是催化新材料、新型催化剂和 催化新工艺有机结合的典型例证, 其每个反应过程能得 以实现都是催化技术创新的结果.

\section{3. 结束语}

以劣质原油为原料生产更多的清洁燃料和优质化 工原料将是今后炼油工业面临的主要挑战和任务. 以提 高轻质油品收率、升级车用燃料质量、生产更多化工原 料为目的, 针对不同的原油品种和不同的石油馏分, 量 体裁衣, 研制高效催化剂, 优化工艺过程, 开发成套的关 键技术才能满足未来炼油工业的发展. RHT, RICP, IHCC, SHF, RSDS, RTS, RS-2000和SHMP等技术都是根 据我国炼油工业的实际和经济发展的需求开发的世界 先进或领先的技术, 将在炼油厂未来的发展中发挥支撑 作用. 